\title{
SEISMIC RETROFITTING OF A DAMAGED SCHOOL BUILDING
}

\author{
Anusha Rani ${ }^{1}$, D. K. Paul ${ }^{2}$ \\ ${ }^{I}$ M.Tech Student, CoEDMM, IIT, Roorkee, India \\ ${ }^{2}$ Emeritus Fellow, Department of Earthquake Engineering, IIT, Roorkee, India
}

\begin{abstract}
Lessons learnt from past devastating earthquakes repeatedly emphasize on importance of school buildings. In our country performance of school structures are worst in past earthquakes and increase vulnerability of school buildings for damage had multiplied the intensity of impact on society after earthquake occurrence. Collapse of school buildings causes loss of lives of most sensitive part of society i.e. children. The loss to children has huge impact on the community. The school also serve as shelter to homeless during the earthquake. Role of schools in pre and post scenario of earthquake event demand Immediate Occupancy level performance. A large number of school buildings are not earthquake resistant. It is economically not feasible to demolish and build again all these important buildings with earthquake resistant features. Structural engineers have developed a number of retrofitting techniques which can be used to upgrade the performance level of existing structure. In this paper as a case study a school building which has suffered damage in $18^{\text {th }}$ September 2011 earthquake, has been evaluated and retrofitting measures have been suggested to upgrade performance level of the building to make it safer against future earthquakes.
\end{abstract}

Keywords: School building; Damage; Earthquake; Immediate Occupancy; Fibre Reinforced Polymer: Retrofitting $* * *$

\section{INTRODUCTION}

School buildings have immense importance in pre and post earthquake scenario. Damage or collapse of these structures can magnify the impact of disasters, and in past severe earthquakes it has been observed that failure of these building had created havoc among the society. Collapse of school buildings caused death of children in past major earthquakes. Death and injuries to children usually have psycho-social impact on society which ultimately increases the impact of earthquakes manifold. Another important use of school buildings is as a temporary shelter for people who lost their accommodation in the event. Sometimes in case of damaged or collapsed school buildings, administration would not be able to find place to use as relief and distribution centre and feels helpless to tackle these situations. But unfortunately such situations have arisen many times in past major earthquake events like Bhuj 2001 and Sikkim 2011 earthquakes. These structures have important role to play after devastating earthquake event and Immediate Occupancy (IO) level performance is required for such important buildings. In our country large numbers of school buildings are seismically deficient. Economical solutions for the safety these important buildings are only in up gradation which makes these buildings resilient for future earthquake events. Retrofitting is only technique through where earthquake resistant features can be incorporated in existing buildings.

\section{PERFORMANCE IN PAST EARTHQUAKES}

School buildings have shown poor performance during past major earthquakes. In 2001 Bhuj earthquake, damages to school buildings are much higher than hospital buildings. In this event 1884 school buildings collapsed with total destruction of 5,950 classrooms [15]. About 9593 primary school, 127 higher secondary government schools, and 47 universities/colleges buildings were damaged or destroyed in this event [15]. In 2011 Sikkim earthquake about 600 school buildings have suffered extensive damage or collapse [16] (Fig 1).Due to damages in school buildings, government was also deprived of use of these buildings as relief camps and emergency service centre in post earthquake scenario.

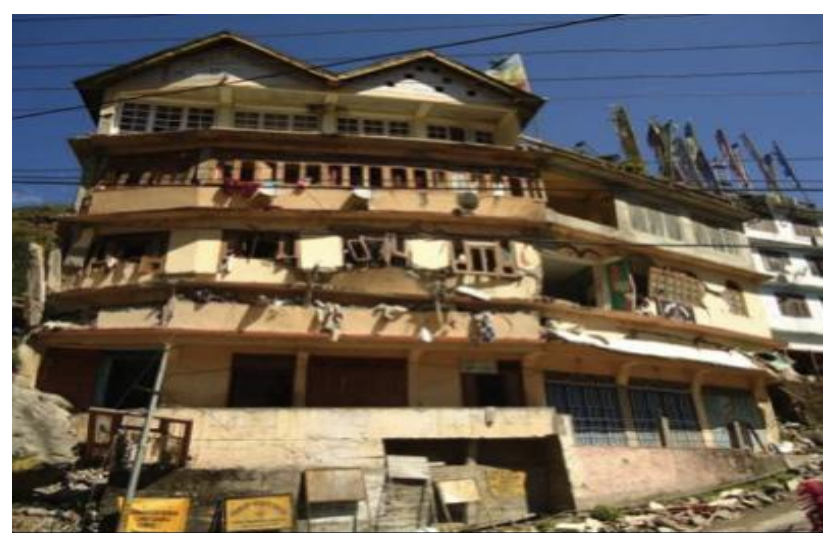

Fig 1: Collapse of one inter-mediate story in of the Moonlight School five-story RC frame building at Chungthang, Sikkim [16]. 


\section{SEISMIC EVALUATION AND RETROFITTING}

Reasons of damages to these buildings are various, but among all reasons the most common are poor design procedure, use of poor building material and poor construction techniques. Most of the buildings suffers damage during earthquakes since these have not been constructed as per design feature of earthquake resistant building of IS 1893:2002 [13]. Some of the school buildings are even not designed as per IS 456 codal guidelines. School buildings should be designed to Immediate Occupancy (IO) level performance in a major seismic event. IO level performance allows very limited structural damage and has negligible risk of life threatening injury from structural failure [5]. To make existing school earthquake resistant, it is very essential to find or evaluate current performance level of structure under site specific earthquake demand. After evaluation of performance level of existing structure, retrofitting measure can be suggested. In this paper a case study of a school building has been taken for seismic evaluation and retrofitting with increased performance level.

\subsection{Description of Building Studied}

Studied block of school building is made of reinforced concrete frame with infill as brick masonry. In the seismic event of $18^{\text {th }}$ September 2011, block has suffered damage in the form of cracks in columns of the corridor and bathroom area (Fig 2). The school building was constructed in 1985 according to seismic code IS 1893:1975[12] and IS 456:1978[8]. Grade of concrete and steel used for construction are M15 and Fe250 respectively. Plan of school building is asymmetric and also block has two parts in longitudinal direction separated by crumple joint of $0.10 \mathrm{~m}$. The school building block is a two storey. The roof is covered with steel trusses. Water tank is installed on the roof of smaller part of block. Ground floor of block is used for classrooms and the first floor is used as library, store room and laboratories. Plan dimension of building block is $49.1 \times 9.5 \mathrm{~m}$. In longitudinal direction, lengths of two parts are 28 and $21 \mathrm{~m}$ respectively and separated by $0.10 \mathrm{~m}$ gap.

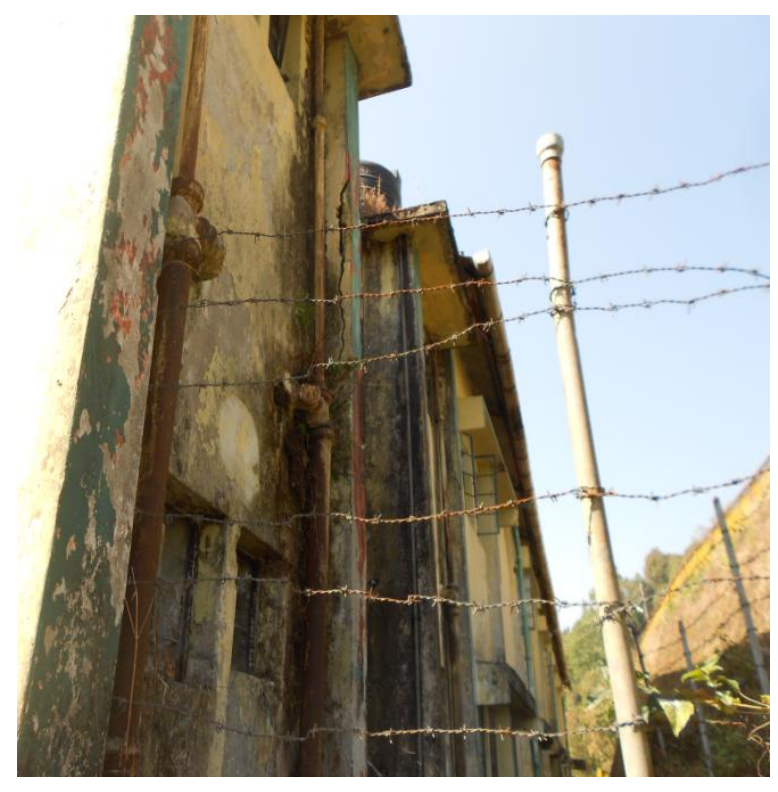

Fig 2: Damage of column around bathroom area

\subsection{Modelling}

A block of school building has been modelled using SAP 2000 software. A 3D model of the block is made for analysis since block is asymmetric in plan (Fig 3). Beams and columns have been modelled as frame elements. The slabs have been assumed as rigid diaphragms; therefore ground and first floors are modelled as rigid diaphragms. Steel trusses and purlins are modelled as frame elements. The base of 3D frame building model is considered fixed to calculate the earthquake response. Initial stiffness of beams and columns has been taken as $0.5 \mathrm{E}_{\mathrm{c}} \mathrm{I}_{\mathrm{g}}$ and $0.7 \mathrm{E}_{\mathrm{c}} \mathrm{I}_{\mathrm{g}}$ respectively, since initial stiffness corresponds to fully cracked section stiffness in case of existing buildings [3].

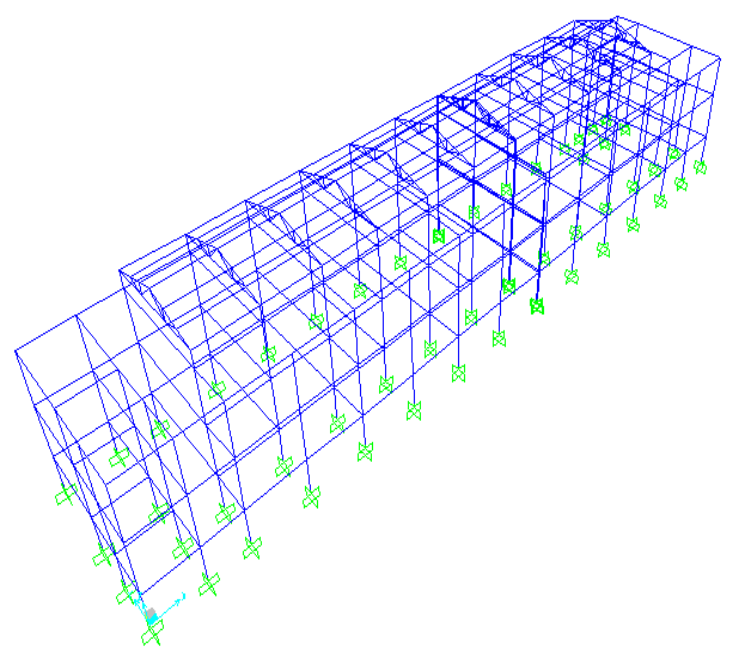

Fig 3: 3D Model of School Building Block 


\subsection{Loading and Load Combinations}

The weight of floor slabs, corridor slabs, staircase slabs, roof truss members, columns, beams, external wall, and partition walls have been considered for dead weight calculation. The dead weight of Watertank has been taken for full capacity storage i.e. 400gals. Dead loads of slabs are distributed to surrounding beam in trapezoidal and triangular loading according to yield line pattern [9]. The dead weight of masonry walls are uniformly distributed to beams. The walls are constructed with brick masonry having unit weight of $20 \mathrm{kN} / \mathrm{m}^{3}$. Density of concrete is taken as $25 \mathrm{kN} / \mathrm{m}^{3}$. Live load on buildings have been taken as per IS: 875(Part 2)1987[11].Earthquake loads are calculated as per IS: 18931975[12]. Gangtok falls under zone IV, therefore Zone factor (Z) is considered as 0.24 [13]. Value of Importance Factor (I) is taken as 1.5 and Response Reduction factor $(\mathrm{R})$ is considered as 3 since ductile detailing have not been done in the building block design. The earthquake loads have been applied in the form of response spectrum. Response spectrum is taken for medium soil and seismic Zone IV [13]. All possible load combinations specified by IS 1893:2002 [13] have been considered to evaluate the safety of the building.

\subsection{Modal Analysis}

To study dynamic response of building modal analysis has been carried out using software. Time periods are evaluated for first three fundamental vibration modes of the building (Table 1).

Table 1: Time Periods (in sec) for first three modes of vibration

\begin{tabular}{|c|c|c|}
\hline Mode No. & Time Period $(\mathrm{Sec})$ & Vibration Mode \\
\hline 1 & 0.769 & Longitudinal \\
\hline 2 & 0.584 & Torsional \\
\hline 3 & 0.558 & Transverse \\
\hline
\end{tabular}

\subsection{Nonlinear Static Pushover Analysis}

For a retrofit analysis, first and necessary step is evaluation of capacity of the structure to resist demand of site specific earthquake through a nonlinear analysis. A nonlinear static pushover analysis includes method like Capacity Spectrum Method or Displacement Coefficient Method to determine capacity of structure. Pushover curve is plotted in the method which is a graphical representation of global forcedisplacement curve of structures [3]. Pushover curve is compared with response spectra (which represent seismic demand) and performance point (which is a intersection point of capacity and demand curve) of existing building is evaluated. Intended performance objective is compared with performance point using FEMA-356 [6]. Performance of 3D computer model of school building is evaluated using SAP
2000 through nonlinear analysis for Design Basis Earthquake (DBE) and Maximum Considered Earthquake (MCE). Using the guidelines of FEMA-356 [6], nonlinear plastic hinges are assigned to beams and columns. The flexural hinges (M3) are assigned for the beams at two ends. The interacting P-M2-M3 frame hinges are assigned to all columns at lower and upper ends. Expected yield strength of concrete and steel are used for nonlinear analysis [3].

\subsection{Analysis of Results}

Pushover analysis is performed using software along $\mathrm{X}$ and $\mathrm{Y}$ directions and pushover curves are plotted (Figs 5and 6). Base shear and roof displacement at performance point is found out using ATC-40[3] (Table 2). The status of performance has also been evaluated in terms of number of hinges for DBE and MCE level of earthquakes (Table 3). Existing component response has been evaluated by hinge performance point defined by ATC-40[3] (Fig 7) in which B, C, D, and E represent effective yield point, yielding with strain hardening, strength degradation and final collapse respectively. Between points $\mathrm{B}$ and $\mathrm{C}$ three more points Immediate Occupancy (IO), Life Safety (LS) and Collapse Prevention (CP) are introduced to define acceptance hinge criteria [2]. To have IO level performance no hinges should be in the range of IO-LS. But in the analysis for school building some hinges are located in IOLS category under MCE level demand. IO-LS level hinges have appeared at the same location where damages have been observed after the Sikkim earthquake of September 2011. Location of formation of these hinges has been found in columns of bathroom areas and corridors mostly (Fig 3). Hinges have appeared in column before formation of hinges in beam which shows reinforced concrete frame designed as Weak column-Strong beam design concept. For ductility in the structure design should be based on Strong column-Weak beam concept.

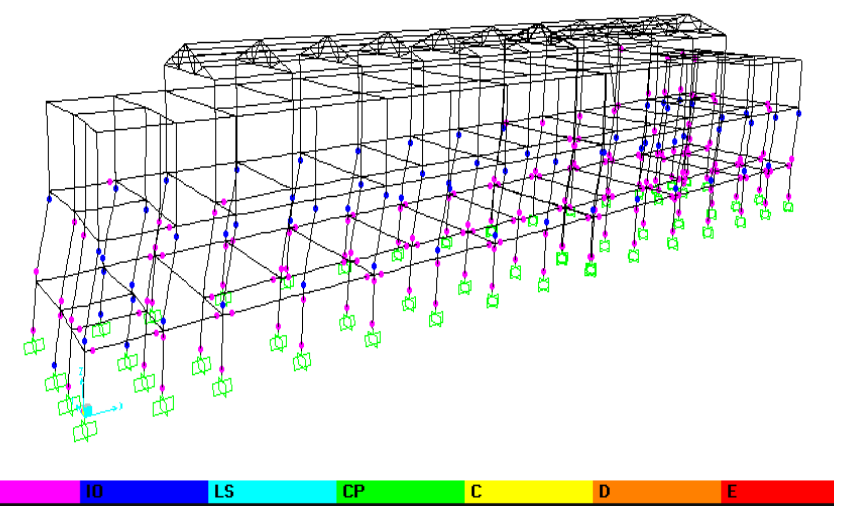

Fig 4: Location of formation of hinges at performance point for MCE level earthquake 


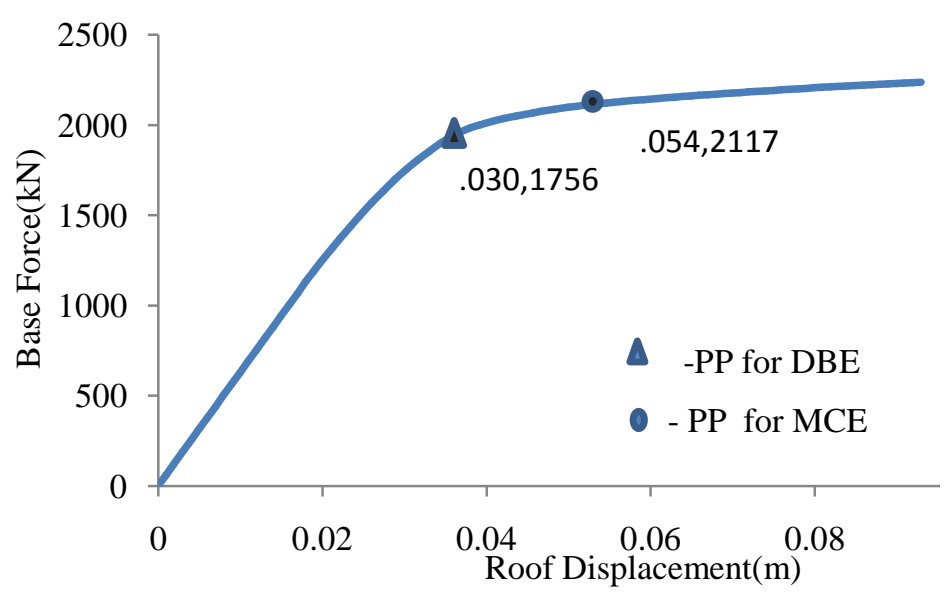

Fig 5: Pushover curve along X (longitudinal)-direction

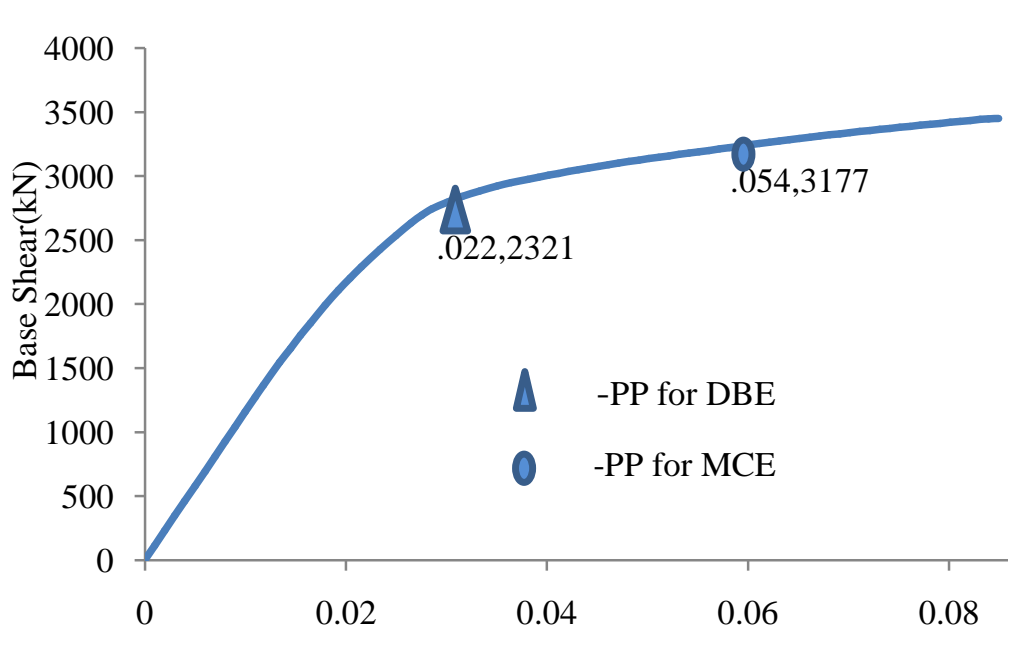

Roof Displacement $(\mathrm{m})$

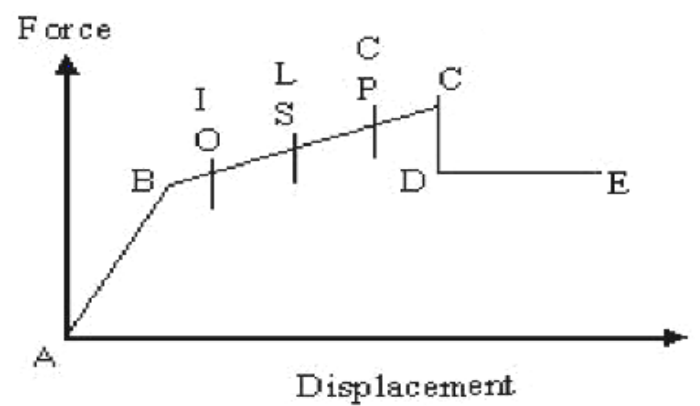

Fig 7: Different stages of plastic hinge

Table 2: Base Shear and Roof Displacement at Performance Point in $\mathrm{X}$ and $\mathrm{Y}$ directions under different earthquake levels

\begin{tabular}{|c|c|c|c|}
\hline Direction & $\begin{array}{c}\text { Earthquake } \\
\text { Level }\end{array}$ & $\begin{array}{c}\text { Base } \\
\text { Shear } \\
\mathrm{V}_{\mathrm{b}}(\mathrm{kN})\end{array}$ & $\begin{array}{c}\text { Roof } \\
\text { Displacement }(\mathrm{mm})\end{array}$ \\
\hline \multirow{2}{*}{$\mathrm{X}$} & $\mathrm{DBE}$ & 1756 & 30 \\
\cline { 2 - 4 } & MCE & 2117 & 54 \\
\hline \multirow{2}{*}{$\mathrm{Y}$} & $\mathrm{DBE}$ & 2321 & 22 \\
\cline { 2 - 4 } & MCE & 3177 & 54 \\
\hline
\end{tabular}

Fig 6: Pushover curve along Y (transverse)-direction

Table 3: Number of Hinges in each range at performance point

\begin{tabular}{|c|c|c|c|c|c|c|c|c|c|c|}
\hline Direction & Earthquake Level & A-B & B-IO & IO-LS & LS-CP & CP-C & C-D & D-E & $>$ E & Total \\
\hline \multirow{2}{*}{ X } & DBE & 743 & 71 & 0 & 0 & 0 & 0 & 0 & 0 & 814 \\
\cline { 2 - 12 } & MCE & 559 & 187 & 68 & 0 & 0 & 0 & 0 & 0 & 814 \\
\hline \multirow{2}{*}{ Y } & DBE & 765 & 49 & 0 & 0 & 0 & 0 & 0 & 0 & 814 \\
\cline { 2 - 11 } & MCE & 660 & 120 & 34 & 0 & 0 & 0 & 0 & 0 & 814 \\
\hline
\end{tabular}

\section{RETROFITTING}

The columns showing damage in the form of formation of hinges need to be retrofitted using suitable retrofitting techniques for building. Retrofitting is a technique by which strength, ductility and stiffness of building is enhanced and final goal of the technique is enhancement of performance level of structure. Global and member level retrofitting usually adopted to increase performance level and to make existing structure to perform for desired performance level against the design earthquake. In this school building, failed component of structure is columns, and column is critical in the participation in lateral load resistance. Therefore, member level retrofitting technique can be applied in present case. Following Procedure is suggested to carry out the retrofitting of the school building. 
Steel/ RC Jacketing: Jacketing of column is one of the member level retrofit techniques. It improves the axial and shear strength of column in uniform and distributed way [1]. To improve lateral load capacity of building, jacketing of weak columns are generally carried out in form of reinforced concrete jackets or steel jackets [1].

FRP (Fibre Reinforced Polymer) overlay on columns: Winding of high strength carbon/glass fibre around column surface at the location of formation of hinges enhances lateral load resisting capacity of column [1]. FRP is widely used for retrofitting due to its properties of high degree of confinement, lightweight, and flexibility in application.

\subsection{Retrofitting Technique}

Retrofitting is done for MCE level earthquake so that IO level performance can be achieved and IO-LS level hinges are brought to B-IO level. Total 22 number of columns are retrofitted in which IO-LS level hinges have appeared either in $\mathrm{X}$ or $\mathrm{Y}$ direction pushover analysis. The damaged columns of school building block are retrofitted using Glass Fibre Reinforced polymer. GFRP (Glass FRP) is wrapped on hinge and nonhinge regions of columns. Required thickness of GFRP is calculated and designed for hinge and nonhinge regions based on the deficiency of lateral load resisting capacity [7]. $\mathrm{V}_{\mathrm{c}}, \mathrm{V}_{\mathrm{N}}$ and $\mathrm{V}_{\mathrm{s}}$ contributes to seismic strength of unstrengthened column where $\mathrm{V}_{\mathrm{c}}$ is shear strength due to concrete depending on ductility, $\mathrm{V}_{\mathrm{N}}$ and $\mathrm{V}_{\mathrm{s}}$ represents shear strength contribution due to axial load and transverse steel respectively [7]. $\mathrm{V}_{\mathrm{o}} / \phi_{\mathrm{v}}$ is the actual shear demand of column where $V_{o}$ is shear demand based on full flexural overstrength in plastic hinges, and $\phi_{\mathrm{v}}$ is strength reduction factor respectively. Difference of shear demand and capacity can be provided by shear capacity of FRP jackets. Shear strength $V_{\text {frp }}$ and thickness $t_{\text {frp }}$ of frp jacket is given by [7],

$$
\begin{gathered}
\mathrm{V}_{\mathrm{frp}}=2 * f * d * \operatorname{Cot} \theta \\
\mathrm{t}_{\mathrm{frp}}=\left(\mathrm{V}_{\mathrm{O}} / \phi_{\mathrm{V}}-\left(\mathrm{V}_{\mathrm{C}}+\mathrm{V}_{\mathrm{N}}+\mathrm{V}_{\mathrm{S}}\right)\right) /\left(2 * \mathrm{f}_{\mathrm{frp}}, \mathrm{e} * \mathrm{~d} * \cot \theta\right)
\end{gathered}
$$

Where $\mathrm{f}_{\text {frp,e }}$ is stress in the FRP corresponding to strain limit of $.004, \mathrm{~d}$ is the dimension in loading direction and $\Theta$ is inclination of shear crack to the column axis generally taken as $45^{\circ}[7]$. Using eqn (2) thickness of column is found out and given below (Table 4). According to available thickness of GFRP, numbers of layers of GFRP are wrapped on columns.

Table 4: Thickness of FRP required in hinge and nonhinge regions of columns

\begin{tabular}{|l|c|c|c|c|}
\hline Column Id & $\begin{array}{c}\text { Additional shear } \\
\text { strength required in } \\
\text { hinge region }(\mathrm{kN})\end{array}$ & $\begin{array}{c}\text { Additional shear } \\
\text { strength required in } \\
\text { nonhinge region }(\mathrm{kN})\end{array}$ & $\begin{array}{c}\text { Thickness of frp } \\
\text { in hinge region } \\
(\mathrm{mm})\end{array}$ & $\begin{array}{c}\text { Thickness of frp in } \\
\text { nonhinge region (mm) }\end{array}$ \\
\hline C1-73 & 19.481 & 0.193 & 0.406 & Not Required \\
\hline C1-74 & 64.008 & 44.720 & 1.333 & 0.93 \\
\hline C1-75 & 52.533 & 33.245 & 1.094 & 0.69 \\
\hline C1-76 & 53.972 & 34.684 & 1.124 & 0.72 \\
\hline C1-77 & 19.855 & 0.567 & 0.414 & 0.01 \\
\hline C1-81 & 31.952 & 12.665 & 0.666 & 0.26 \\
\hline C1-84 & 80.639 & 61.351 & 1.680 & 1.28 \\
\hline C5-85 & 41.948 & 25.071 & 0.874 & 0.52 \\
\hline C5-87 & 29.466 & 12.590 & 0.614 & 0.26 \\
\hline C4-113 & 5.478 & Not Required & 0.065 & Not Required \\
\hline C5-136 & 13.655 & Not Required & 0.284 & Not Required \\
\hline C5-137 & 17.181 & Not Required & 0.358 & Not Required \\
\hline C1-138 & 30.094 & 10.807 & 0.627 & 0.23 \\
\hline C1-139 & 45.323 & 26.035 & 0.944 & 0.54 \\
\hline C1-140 & 38.85 & 19.57 & 0.81 & 0.41 \\
\hline C1-141 & 42.69 & 23.40 & 0.89 & 0.49 \\
\hline C1-142 & 45.75 & 26.46 & 0.95 & 0.55 \\
\hline C1-143 & 32.48 & 13.19 & 0.68 & 0.27 \\
\hline C1-144 & 22.25 & 2.96 & 0.46 & 0.06 \\
\hline C3-149 & 35.14 & 15.85 & 0.37 & 0.17 \\
\hline C3-150 & 54.11 & 34.83 & 0.56 & 0.36 \\
\hline C3-151 & 55.21 & 35.92 & 0.58 & 0.37 \\
\hline
\end{tabular}




\section{CONCLUSIONS}

It has been observed and felt after every earthquake failure of school buildings has created chaos in society. A large numbers of these deficient structures need to be retrofitted with economical techniques. It has been seen that enhanced performance of these structures can save numbers of lives and make society disaster resilient. Due to importance of school buildings in post disaster scenario, these structures should have IO level performance. To identify the performance of school buildings, first they need to be evaluated. In this paper assessment of damaged reinforced concrete framed school building has been carried out and for damaged columns retrofitting is done. To capture the dynamic response under earthquake forces modal analysis has been done. To evaluate the performance of building block nonlinear pushover analysis has been performed and performance point is calculated for DBE as well as MCE level seismic demand. Analysis of block has revealed that block is safe and has IO level performance for DBE level but under MCE level demand some of the columns have damaged due to formation of hinges at the ends. Member level retrofitting can be applied to increase the seismic resistance capacity of columns. So, using GFRP member level retrofitting is done for damaged columns and thickness of FRP is calculated. And depending on availability of GFRP sheet thickness, number of layers can be applied. Overlaying of GFRP on columns increased seismic shear strength and their performances. By making these structures earthquake resistant for future earthquakes disaster resilient society can be achieved.

\section{REFERENCES}

[1] Agarwal, P. and Shrikhande, M. (2009), "Earthquake Resistant Design of Structures", PHI Learning Private LTD, New Delhi.

[2] ASCE 41-06 (2007), "Seismic Rehabilitation of Existing Buildings", American Society of Civil Engineers, Reston, Virginia.

[3] ATC-40 (1997), "Seismic Evaluation and Retrofit of Concrete Buildings", Applied Technology Council, California.

[4] CSI Analysis Reference Manual for SAP 2000 Version14, Computers and Structures Inc., Berkeley, California.

[5] FEMA-273 (1997), "NEHRP Guidelines for the Seismic Rehabilitation of Buildings", US Federal Emergency Management Agency, Building Seismic Safety Council, Washington DC.

[6] FEMA-356 (2000), "Prestandard and Commentary for the Seismic Rehabilitation of Buildings", US Federal Emergency Management Agency, Washington, D.C.

[7] Teng, J.G., Chen, J.F., Smith, S.T., and Lam, L.(2002), "FRP STRENGTHENED RC STRUCTURES", John Wiley and Sons, Inc. New York.

[8] IS: 456 (1978), "Plain and Reinforced Concrete-Code of Practice", Bureau of Indian Standards, New Delhi
[9] IS: 456 (2000), "Plain and Reinforced Concrete-Code of Practice", Bureau of Indian Standards, New Delhi.

[10] IS: 875(Part I) (1987), "Code of Practice for Design Loads(Other Than Earthquake) for Buildings and Structures- Part 1 Dead Loads-Unit Weights of Building Material and Stored Materials", Bureau of Indian Standards, New Delhi.

[11] IS: 875(Part II) (1987), "Code of Practice for Design Loads(Other Than Earthquake) for Buildings and Structures- Imposed Loads", ”, Bureau of Indian Standards, New Delhi.

[12] IS 1893 (Part 1) (1975), "Criteria for Earthquake Resistant Design of Structures-General Provisions and Buildings", Bureau of Indian Standards, New Delhi.

[13] IS 1893 (Part 1) (2002), "Criteria for Earthquake Resistant Design of Structures-General Provisions and Buildings", Bureau of Indian Standards, New Delhi.

[14] "Learning from Earthquakes: Preliminary Observations on the Origin and Effects of the January 26, 2001 Bhuj (Gujarat, India) Earthquake," EERI Special Earthquake Report - April 2001, EERI Newsletter, Vol. 35, no. 4, Earthquake Engineering Research Institute, Oakland, Ca, April 2001.

[15] Mishra, P.K. (2012), "The Kutch Earthquake 2001 Recollections, Lessons and Insights", NIDM, New Delhi.

[16] Murty, C.V.R., and Sheth A. (2012), "Learning from Earthquakes: The Mw 6.9 Sikkim-Nepal Border Earthquake of September 18, 2011”, EERI Special Earthquake Report - February 2012.

[17] Paulay, T. and Priestley, M.J.N. (1992), "Seismic Design of Reinforced Concrete and Masonry Buildings", John Wiley and Sons, Inc. New York. 